Vol. 9 (2000): 135-147.

\title{
The effect of ammonium ferric hexacyanoferrate on reducing radiocaesium transfer from grass silage to sheep
}

\author{
Arja Paasikallio \\ Agricultural Research Centre of Finland, Resource Management Research, FIN-31600 Jokioinen, \\ Finland, e-mail: arja.paasikallio@mtt.fi \\ Riitta Sormunen-Cristian and Seija Jaakkola \\ Agricultural Research Centre of Finland, Animal Production Research, FIN-31600 Jokioinen, Finland \\ Matti Kaikkonen \\ Department of Basic Veterinary Sciences, PO Box 57, FIN-00014 University of Helsinki, Finland
}

\begin{abstract}
A study was carried out to examine the effect of ammonium ferric hexacyanoferrate (AFCF) on the transfer of radiocaesium from grass silage to the tissues of male lambs. During ensiling, a formic acid based additive and AFCF were sprayed on grass contaminated with ${ }^{134} \mathrm{Cs}$ and the mixture was allowed to incubate for 45 days. A dose of $21 \mathrm{mg} \mathrm{AFCF} \mathrm{d}^{-1}$, fed to sheep offered contaminated silage for fourteen days, reduced ${ }^{134} \mathrm{Cs}$ transfer to muscle by $45 \%$ compared to that of control sheep. An equivalent dose of AFCF administered in a capsule reduced transfer by only $3 \%$. In another experiment, AFCF intake of 50,100 and $150 \mathrm{mg} \mathrm{d}^{-1}$ for ten days reduced ${ }^{134} \mathrm{Cs}$ transfer to sheep muscle by 75,82 and $86 \%$, respectively. In control lambs, of average live weight 38 and $47 \mathrm{~kg}$, the feed to muscle ${ }^{134} \mathrm{Cs}$ transfer coefficient averaged $0.15 \mathrm{~d} \mathrm{~kg}^{-1}$, but equilibrium between tissue and feed ${ }^{134} \mathrm{Cs}$ had probably not been reached due to the short feeding period. Increasing doses of AFCF from 0 to $150 \mathrm{mg} \mathrm{d}^{-1}$ increased the faecal/urinary ${ }^{134} \mathrm{Cs}$ ratio from 2 to 42 .
\end{abstract}

Key words: AFCF, excretion, preservation, radiocaesium, sheep, silage, transfer

\section{Introduction}

Different materials have been administered to ruminants for reducing radiocaesium transfer to meat and milk products. These include bentonite (Andersson 1989, Beresford et al. 1989,
Mitchell et al. 1989), zeolite (Phillippo et al. 1988, Unsworth et al. 1989), vermiculite (Hazzard 1969), kaolin (Giese 1989), stable caesium (Oughton et al. 1991) and crude fibre (Johnson et al. 1968). Organic complexes such as ferric hexacyanoferrates, commonly referred to as 


\section{Paasikallio, A. et al. Effect of AFCF on reducing ${ }^{134}$ Cs transfer from grass silage to sheep}

Prussian Blue (PB) compounds are, however, the most effective caesium binders on a unit weight basis (Giese 1989, Unsworth et al. 1989). PB compounds reduce the intestinal absorption of radiocaesium, and are most effective when administered with contaminated feed. PB compounds react with radiocaesium in the gut to form a complex that is excreted in the faeces. Furthermore, they have been reported to enhance tissue excretion of radiocaesium into the gut (Hove et al. 1990, Nielsen et al. 1990, Åhman 1996). Ammonium ferric hexacyanoferrate (AFCF) is the most commonly used PB compound and binds radiocaesium in the gut in exchange for an ammonium ion. AFCF has been used as a feed supplement in silage and concentrates for housed ruminants and in salt licks and boli for grazing animals (Unsworth et al. 1989, Pearce et al. 1989, Hove et al. 1990, Voigt 1993, Hansen et al. 1996, IAEA 1997). In general, studies have only considered the effects of AFCF mixed with silage some time prior to feeding (Arnaud et al. 1988, Giese 1989, Unsworth et al. 1989, Vreman et al. 1992), while information concerning the use of AFCF at grass harvesting and its effects during and after storage in silo is limited.

In the 1960 s, studies were carried out on the toxicity of PB on animals and humans (Nigrovic 1963, Madhus et al. 1966). After radioactive emissions following the Chernobyl accident, toxicological as well as other studies on PB were revived (Arnaud et al. 1988, Giese 1988, Nielsen et al. 1990, Pearce 1994). The results showed that the consumption of milk and meat from PB treated animals could be considered safe with respect to human health. So far, the application of AFCF to soil directly or via the faeces does not seem to have any negative effects on soil-plant environments (Vandenhove et al. 1997, 1998, 2000). However, long-term and more comprehensive studies are lacking (Jones et al. 1999).

Following the Chernobyl accident, PB compounds were officially approved for use as a feed additive in Russia, Ukraine, Belarus, Norway, Germany and Austria (IAEA 1997). The
EC directive allows the use of AFCF as a feed additive in the EU countries, but its use should be authorized at the national level (Commission Directive 1996). PB compounds have also been used successfully with human casualties of the Goiânia radiation accident in Brazil (Lipsztein et al. 1991, Melo et al. 1994).

This study was carried out to examine the effect of low levels of AFCF, mixed in contaminated grass during ensiling, on the transfer of ${ }^{134} \mathrm{Cs}$ to ovine tissues. The hypothesis tested was that, in situations of radioactive fallout, AFCF could be mixed with contaminated grass at harvesting together with an acid based ensiling additive.

\section{Material and methods}

\section{Preparing ${ }^{134} \mathrm{Cs}$-AFCF-silage}

Ryegrass was grown in pots in peat soil contaminated with ${ }^{134} \mathrm{Cs}$. Grass was harvested after 45 days. One kilogram of contaminated ryegrass was placed on a plastic sheet and thoroughly mixed with $6 \mathrm{~kg}$ of uncontaminated chopped and prewilted timothy-meadow fescue grass. The purpose of prewilting was to minimize silage effluent production. Grass was treated with a formic acid based additive (AIV2-solution containing $80 \%$ formic acid and $2 \%$ orthophosphoric acid) at a rate of $5 \mathrm{ml} \mathrm{kg}^{-1}$. Additive diluted with water $(50 \%)$ was sprayed on grass prior to ensiling. In addition, AFCF (ammonium ferric hexacyanoferrate, $\mathrm{NH}_{4} \mathrm{Fe}^{3+}\left[\mathrm{Fe}^{2+}(\mathrm{CN})_{6}\right]$, containing $33 \% \mathrm{NH}_{4} \mathrm{Cl}$ ) as a water solution was also applied to grass. ACFC was applied at a rate of 0 and $100 \mathrm{mg} \mathrm{kg}^{-1}$ and $0,250,500$ and 750 $\mathrm{mg} \mathrm{kg}^{-1}$ of grass in experiments 1 and 2, respectively. Once applied, grass $(7 \mathrm{~kg})$ was ensiled in laboratory silos (volume of cylinder $15.4 \mathrm{dm}^{3}$, diameter $14 \mathrm{~cm}$ ). Each silo was fitted with a drainage system for collecting and monitoring silage effluent production. After filling, each silo was tightly sealed and weighted with con- 


\section{AGRICULTURAL AND FOOD SCIENCE IN FINLAND}

Vol. 9 (2000): 135-147.

Table 1. Some aspects of experimental conditions (daily AFCF doses, ${ }^{134} \mathrm{Cs}$ intake and sheep parameters).

\begin{tabular}{lrr}
\hline & Experiment 1 & Experiment 2 \\
\hline AFCF doses $\left(\mathrm{mg} \mathrm{d}^{-1}\right.$ sheep $\left.^{-1}\right)$ & $0,21^{\mathrm{a}}, 21$ & $0,50,100,150$ \\
${ }^{134} \mathrm{Cs}$ intake $\left(\mathrm{kBq} \mathrm{d}^{-1}\right.$ sheep $\left.^{-1}\right)$ & 7 & 13 \\
Test period $(\mathrm{d})$ & 14 & 10 \\
& 2 & 3 \\
Number of replicates & 6 & 12 \\
Total number of sheep & 171 & 214 \\
& 38 & 47 \\
Age of sheep (d) & & \\
Live weight $(\mathrm{kg})$ & & \\
\hline
\end{tabular}

${ }^{a} \mathrm{AFCF}$ (ammonium ferric hexacyanoferrate) given in capsule, others in silage

crete blocks and water bags to a pressure of 585 $\mathrm{kg} \mathrm{m}^{-2}$. Preservation lasted for about 45 days. After opening the silos, silage was sampled and divided into daily doses $(0.2 \mathrm{~kg} / \mathrm{sheep})$ and frozen in plastic bags for later use. Fermentation quality of both ${ }^{134} \mathrm{Cs}$ contaminated and uncontaminated silages was good.

\section{Animals and experimental design}

Male crossbred Finnish Landrace lambs, mean age 171 (experiment 1) and 214 days (experiment 2) and live weight of 38 and $47 \mathrm{~kg}$, respectively, were used in the study (Table 1). Lambs were allocated according to live weight into two blocks of three animals (experiment 1) and into three blocks of four animals (experiment 2). Lambs within each block were exposed to different experimental treatments. The animals were individually housed in metabolic cages. Before the experiments started, the animals were allowed 7 days to become accustomed to the cages. In experiment 1 , silage contaminated with ${ }^{134} \mathrm{Cs}$ was given daily to all sheep for fourteen days. AFCF was given either with contaminated silage or in gelatine capsules. Daily intakes of AFCF were 0,21 and $21 \mathrm{mg} \mathrm{d}^{-1}$ for control, treated silages and AFCF capsules (two sheep each), respectively. In experiment 2 , contaminated silage with different AFCF doses was given to twelve sheep for ten days. The intake of AFCF in silage were $0,50,100$ and $150 \mathrm{mg} \mathrm{d}^{-1}$ for three sheep each (Table 1). Experiments 1 and 2 were conducted in September 1995 and October 1996, respectively.

\section{Feeding and sampling}

In both experiments, the sheep received a daily ration fed in the mornings, consisting of $3 \mathrm{~kg}$ of uncontaminated farm silage, $0.3 \mathrm{~kg}$ of barley and $0.2 \mathrm{~kg}$ of ${ }^{134} \mathrm{Cs}$ contaminated silage (with or without AFCF). When AFCF (21 $\mathrm{mg} \mathrm{d}^{-1}$ ) was given in a capsule, the capsule was administered immediately after the morning feed (experiment 1). The daily feed intake of each animal was recorded in both experiments. Water was available ad libitum with consumption recorded for all experimental animals. Urine and faeces were collected separately and output was measured daily. Sub-samples of urine and faeces were stored frozen prior to ${ }^{134} \mathrm{Cs}$ determinations. At the end of both experiments, the animals were slaughtered and sampled. In experiment 1, dorsal and femural muscle, heart, liver, kidney, whole blood and digesta samples were col- 


\section{Paasikallio, A. et al. Effect of AFCF on reducing ${ }^{134}$ Cs transfer from grass silage to sheep}

lected. For the second experiment, samples of neck and femural muscle, diaphragm, heart, liver and kidney were collected. In all cases, samples were stored frozen and subsequently monitored for ${ }^{134} \mathrm{Cs}$.

\section{Sample analysis}

For activity measurement animal tissues were cut into small pieces. Visible fat was removed from samples of muscle and kidney. The ${ }^{134} \mathrm{Cs}$ activity concentration of contaminated grass silage, urine, faeces and animal tissues was determined using a low-background semiconductor spectrometer coupled to a germanium detector. Activity concentrations of ${ }^{134} \mathrm{Cs}$ are presented on a fresh weight (FW) basis. Transfer coefficients of ${ }^{134} \mathrm{Cs}\left(\mathrm{d} \mathrm{kg}^{-1}\right)$ from feed to tissues was calculated as ${ }^{134} \mathrm{Cs}$ activity concentration in tissues $\left(\mathrm{Bq} \mathrm{kg}{ }^{-1}\right)$ per ${ }^{134} \mathrm{Cs}$ intake $\left(\mathrm{Bq} \mathrm{d}^{-1}\right)$.

\section{Statistical methods}

In both experiments, the effect of AFCF treatments on tissue ${ }^{134} \mathrm{Cs}$ activity concentration was evaluated by Analysis of Variance for repeated measures using the MIXED PROCEDURE within SAS (SAS 1992). Repeated measurements within each animal were found to be highly correlated, a factor which was taken into account by using a compound symmetry covariance structure assigned on the basis of Akaike's and Scharz's Bayesian information criteria (Wolfinger 1996). The statistical model (Gumperetz and Brownie 1993) used to assess the effect of treatments was:

$\mathrm{Y}_{\mathrm{ijk}}=\mu+\mathrm{A}_{\mathrm{i}}+\mathrm{B}_{\mathrm{j}}+\mathrm{e}_{\mathrm{ij}}+\mathrm{T}_{\mathrm{k}}+(\mathrm{AT})_{\mathrm{jk}}+(\mathrm{BT})_{\mathrm{ik}}+\mathrm{h}_{\mathrm{ijk}}$

where $\mathrm{Y}_{\mathrm{ijk}}$ is the observed response (e.g. ${ }^{134} \mathrm{Cs}$ activity concentration), $\mu$ is the intercept, $A_{i}$ the fixed effect from the ith treatment, $B_{j}$ the random block effect. $\mathrm{e}_{\mathrm{ij}}$ is a random effect that represents the error associated with the ijth cell. $T_{k}$ and $(\mathrm{AT})_{\mathrm{jk}}$ represent the fixed effect of tissue and treatment-tissue interactions, respectively, while $(\mathrm{BT})_{\mathrm{ik}}$ is the random effect of block-tissue interaction and $h_{i j k}$ are error terms.

Due to a low activity concentration in blood (experiment 1), the effect of different AFCF treatments on ${ }^{134} \mathrm{Cs}$ activity concentration in blood was analyzed separately by Analysis of Variance for a randomized complete block design as follows:

$\mathrm{Y}_{\mathrm{ij}}=\mu+\mathrm{A}_{\mathrm{i}}+\mathrm{B}_{\mathrm{j}}+\mathrm{e}_{\mathrm{ij}}$

where $Y_{i j}, \mu, A_{i}, B_{j}$ and $e_{i j}$ are equivalent to those in the previously described model.

Differences between treatments and between tissues were tested using orthogonal contrasts. In experiment 2, linear and quadratic effects of AFCF treatment were studied. Prior to analysis, data concerning ${ }^{134} \mathrm{Cs}$ activity concentration was transformed into natural logarithms to the constancy of error variance. Assumptions of both models were checked using graphical methods i.e. box-plot for normality and plots of residuals to ensure constancy of error.

\section{Results}

\section{Experiment I}

The sheep consumed their whole feed ration. When AFCF (21 $\left.\mathrm{mg} \mathrm{d}^{-1}\right)$ was administered to sheep as a capsule for fourteen days, the ${ }^{134} \mathrm{Cs}$ activity concentration of tissues except the liver did not differ from that of the controls. When an equivalent dose of AFCF was administered in silage, the average transfer of ${ }^{134} \mathrm{Cs}$ to tissues was reduced to $50 \%$ of that of controls (Table 2). Activity concentrations of ${ }^{134} \mathrm{Cs}$ differed significantly $(\mathrm{P}<0.05)$ between tissues in controls, being highest in kidneys and lowest in muscle. The feed to muscle transfer coefficient for ${ }^{134} \mathrm{Cs}$ in control sheep was twice as high as in animals treated with AFCF administered in silage (Table 3). 
Vol. 9 (2000): 135-147.

Table 2. Activity concentration (least square mean with $95 \%$ confidence interval) and reduction ( $\%$ of control) of ${ }^{134} \mathrm{Cs}$ in sheep tissues after administering ${ }^{134} \mathrm{Cs}$ contaminated silage daily, without ammonium ferric hexacyanoferrate (AFCF) (control) and with $21 \mathrm{mg} \mathrm{d}^{-1}$ of AFCF given as a capsule or in silage fed for 14 days (experiment 1).

\begin{tabular}{|c|c|c|c|c|c|c|c|c|}
\hline \multirow[t]{3}{*}{ Tissue } & \multicolumn{5}{|c|}{${ }^{134} \mathrm{Cs}$ in sheep } & \multicolumn{3}{|c|}{ Significance } \\
\hline & \multirow{2}{*}{$\frac{\text { Control }}{\left(\mathrm{Bq} \mathrm{kg}^{-1}\right)}$} & \multicolumn{2}{|c|}{ AFCF $21 \mathrm{mg} \mathrm{d}^{-1}$ (capsule) } & \multicolumn{2}{|c|}{ AFCF $21 \mathrm{mg} \mathrm{d}^{-1}$ (silage) } & \multirow[b]{2}{*}{$\mathrm{P}_{1}$} & \multirow[b]{2}{*}{$\mathrm{P}_{2}$} & \multirow[b]{2}{*}{$\mathrm{P}_{3}$} \\
\hline & & $\left(\mathrm{Bq} \mathrm{kg}^{-1}\right)$ & $(\%)$ & $\left(\mathrm{Bq} \mathrm{kg}^{-1}\right)$ & $(\%)$ & & & \\
\hline Muscle & $\begin{array}{c}961 \\
(770,1199)\end{array}$ & $\begin{array}{c}942 \\
(755,1176)\end{array}$ & 3 & $\begin{array}{c}522 \\
(418,651)\end{array}$ & 46 & 0.89 & $<0.005$ & $<0.005$ \\
\hline Heart & $\begin{array}{c}1163 \\
(932,1452)\end{array}$ & $\begin{array}{c}960 \\
(769,1198)\end{array}$ & 17 & $\begin{array}{c}559 \\
(448,697)\end{array}$ & 52 & 0.18 & $<0.005$ & 0.01 \\
\hline Liver & $\begin{array}{c}1483 \\
(1189,1851)\end{array}$ & $\begin{array}{c}918 \\
(736,1146)\end{array}$ & 38 & $\begin{array}{c}598 \\
(479,746)\end{array}$ & 60 & 0.01 & $<0.001$ & 0.02 \\
\hline Kidney & $\begin{array}{c}2032 \\
(1628,2536)\end{array}$ & $\begin{array}{c}1773 \\
(1420,2212)\end{array}$ & 13 & $\begin{array}{c}1011 \\
(810,1262)\end{array}$ & 50 & 0.33 & $<0.005$ & $<0.005$ \\
\hline Whole blood & $\begin{array}{c}127 \\
(47,339)\end{array}$ & $\begin{array}{c}84 \\
(31,225)\end{array}$ & 34 & $\begin{array}{c}54 \\
(20,146)\end{array}$ & 57 & 0.33 & 0.12 & 0.31 \\
\hline
\end{tabular}

Number of sheep per treatment $=2$, muscle is a mean of dorsal and femural muscles, $\mathrm{P}_{1}=$ control vs. AFCF (capsule), $\mathrm{P}_{2}=$ control vs. AFCF (silage), $\mathrm{P}_{3}=\mathrm{AFCF}$ (capsule) vs. AFCF (silage)

Table 3. Transfer coefficients of ${ }^{134} \mathrm{Cs}$ (muscle/silage) for sheep administered daily with different doses of ammonium ferric hexacyanoferrate (AFCF).

\begin{tabular}{|c|c|c|c|c|}
\hline \multirow{3}{*}{$\begin{array}{l}\mathrm{AFCF} \\
\text { dose } \\
\left(\mathrm{mg} \mathrm{d}^{-1}\right)\end{array}$} & \multirow[b]{3}{*}{$\mathrm{n}$} & \multirow{3}{*}{$\begin{array}{l}\text { Test } \\
\text { period } \\
\text { (d) }\end{array}$} & \multirow{2}{*}{\multicolumn{2}{|c|}{$\begin{array}{c}{ }^{134} \mathrm{Cs} \\
\text { transfer coefficient } \\
\left(\mathrm{d} \mathrm{kg}^{-1}\right)\end{array}$}} \\
\hline & & & & \\
\hline & & & Mean & $\mathrm{SD}$ \\
\hline \multicolumn{5}{|c|}{ Experiment 1} \\
\hline 0 & 2 & 14 & 0.14 & 0.01 \\
\hline $21^{\mathrm{a}}$ & 2 & 14 & 0.14 & $<0.01$ \\
\hline 21 & 2 & 14 & 0.07 & 0.02 \\
\hline \multicolumn{5}{|c|}{ Experiment 2} \\
\hline 0 & 3 & 10 & 0.16 & 0.03 \\
\hline 50 & 3 & 10 & 0.04 & 0.01 \\
\hline 100 & 3 & 10 & 0.03 & 0.01 \\
\hline 150 & 3 & 10 & 0.03 & 0.01 \\
\hline
\end{tabular}

$\mathrm{n}=$ number of sheep, $\mathrm{SD}=$ standard deviation

a AFCF given in capsule, others in silage 
Paasikallio, A. et al. Effect of AFCF on reducing ${ }^{134}$ Cs transfer from grass silage to sheep

Table 4. Activity concentration of ${ }^{134} \mathrm{Cs}$ in digesta after administering ${ }^{134} \mathrm{Cs}$ contaminated silage daily, without ammonium ferric hexacyanoferrate (AFCF) (control) and AFCF given as a capsule or in silage fed for 14 days (experiment 1).

\begin{tabular}{|c|c|c|c|c|c|c|c|c|c|}
\hline \multirow[t]{4}{*}{ Gastrointestinal site } & \multicolumn{9}{|c|}{${ }^{134} \mathrm{Cs}$ in digesta $\left(\mathrm{Bq} \mathrm{kg}^{-1}\right)$} \\
\hline & \multicolumn{3}{|c|}{ Control } & \multicolumn{3}{|c|}{ AFCF (capsule) } & \multicolumn{3}{|c|}{ AFCF (silage) } \\
\hline & \multirow[b]{2}{*}{$\mathrm{n}$} & \multirow[b]{2}{*}{ Mean } & \multirow[b]{2}{*}{$\mathrm{SD}$} & \multicolumn{6}{|c|}{$21 \mathrm{mg} \mathrm{d}^{-1}$} \\
\hline & & & & $\mathrm{n}$ & Mean & SD & $\mathrm{n}$ & Mean & SD \\
\hline Rumen & 2 & 403 & 79 & 2 & 254 & 79 & 2 & 575 & 115 \\
\hline Omasum & 2 & 495 & 138 & 1 & 510 & - & 1 & 1626 & - \\
\hline Abomasum & 2 & 391 & 33 & 2 & 406 & 6 & 2 & 877 & 11 \\
\hline Duodenum & 1 & 408 & - & 2 & 388 & 18 & & & \\
\hline Jejunum, oral+aboral & 2 & 576 & 48 & 2 & 483 & 131 & 2 & 526 & 60 \\
\hline L.intestine+caecum & 2 & 1313 & 26 & 2 & 1425 & 32 & 1 & 2356 & - \\
\hline L.intestine, prox. & 1 & 1761 & - & 2 & 1805 & 262 & 2 & 2397 & 129 \\
\hline L.intestine, dist. & 1 & 3279 & - & & & & 2 & 4209 & 1129 \\
\hline L.intestine+rectum & & & & 1 & 3536 & - & & & \\
\hline Rectum & 1 & 2766 & - & 1 & 2462 & - & & & \\
\hline
\end{tabular}

$\mathrm{n}=$ number of sheep, $\mathrm{SD}=$ standard deviation, data are given in fresh weight

Gastrointestinal tract contents had higher ${ }^{134} \mathrm{Cs}$ activity concentrations in $\mathrm{AFCF}$ (silage)-treated sheep than in the other treatment groups. In general, the ${ }^{134} \mathrm{Cs}$ level of digesta tended to increase towards the posterior part of gastrointestinal tract being highest in the distal part of the large intestine (Table 4).

Excretion of ${ }^{134} \mathrm{Cs}$ expressed as a $\%$ of ${ }^{134} \mathrm{Cs}$ intake was greater in faeces than urine (Table 5). Urinary ${ }^{134} \mathrm{Cs}$ excretion was significantly $(\mathrm{P}<$ 0.001 ) higher in sheep fed the control diet. Faecal ${ }^{134} \mathrm{Cs}$ excretion increased continuosly before reaching a plateau after 5-6 days (Fig. 1).

\section{Experiment 2}

During the first day two sheep refused to consume silage. After this, the sheep consumed all given feed. Tissue ${ }^{134} \mathrm{Cs}$ activity concentrations were clearly higher in control animals than in those treated with AFCF, therefore controls were not included in further comparisons be- tween treatments. Caesium 134 activity concentration of tissues except the liver differed significantly $(\mathrm{P}<0.05)$ between the three AFCFtreatments. When AFCF was given to sheep at 50,100 and $150 \mathrm{mg} \mathrm{d}^{-1}$ in silage for ten days, ${ }^{134} \mathrm{Cs}$ transfer to muscle reduced by 75,82 and $86 \%$ relative to control values, respectively (Table 6). In control animals, the ${ }^{134} \mathrm{Cs}$ activity concentration in kidneys was significantly $(\mathrm{P}<$ 0.001 ) higher than that determined in all other tissues. The feed to muscle transfer coefficient of ${ }^{134} \mathrm{Cs}$ was $0.16 \mathrm{~d} \mathrm{~kg}^{-1}$ in controls, while for AFCF-treated sheep, a value around $0.03 \mathrm{~d} \mathrm{~kg}^{-1}$ was observed (Table 3 ).

Faecal excretion of ${ }^{134} \mathrm{Cs}$ was clearly lower, and urinary excretion higher, in control sheep than in AFCF-treated sheep (Fig. 2). There were, however, only negligible differences in ${ }^{134} \mathrm{Cs}$ excretion between AFCF treatments (Table 5). Daily water intake of individual animals varied from 0.07 to $1.81 \mathrm{~d} \mathrm{~d}^{-1}$. Feed and water intakes were not affected by the AFCF-treatments. 
Vol. 9 (2000): 135-147.

a)

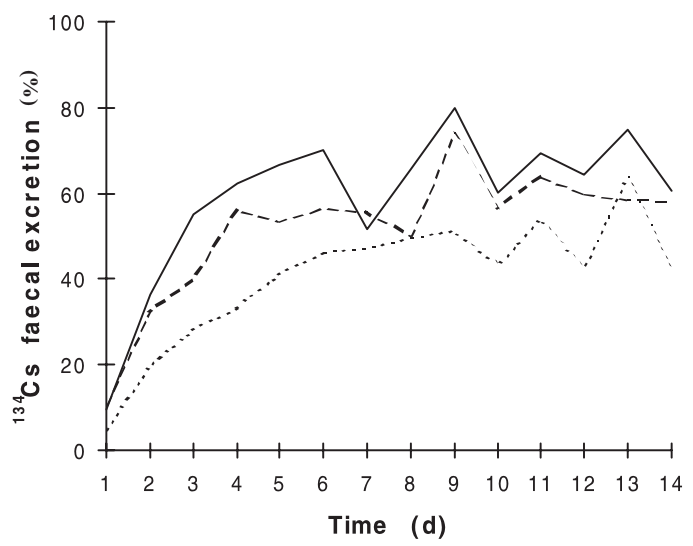

b)

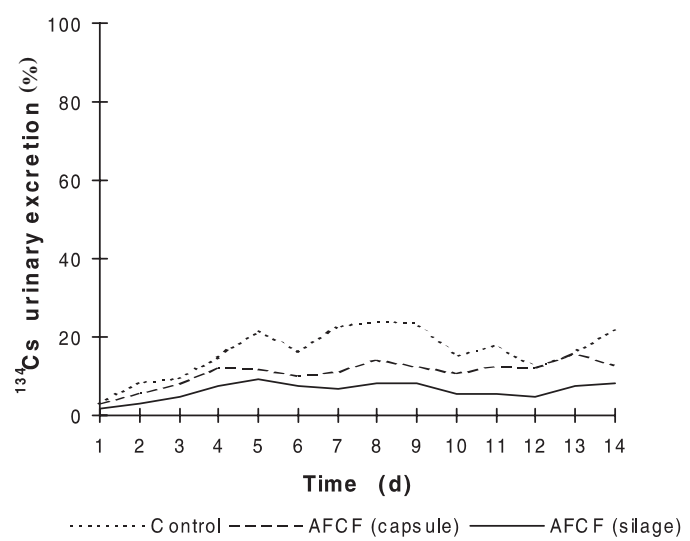

Fig. 1. Effect of ammonium ferric hexacyanoferrate (AFCF) $\left(21 \mathrm{mg} \mathrm{d}^{-1}\right)$ administered in a capsule or in silage on ${ }^{134} \mathrm{Cs}$ faecal (a) and urinary (b) excretion (\% of intake) during fourteen days. (experiment 1)

a)

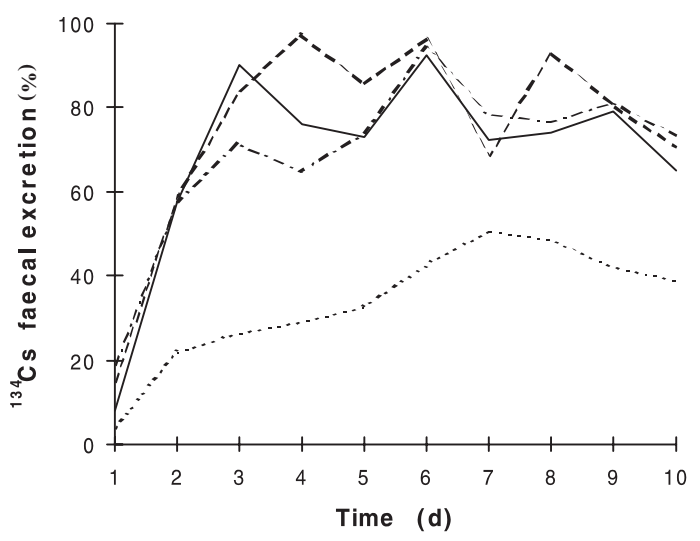

b)

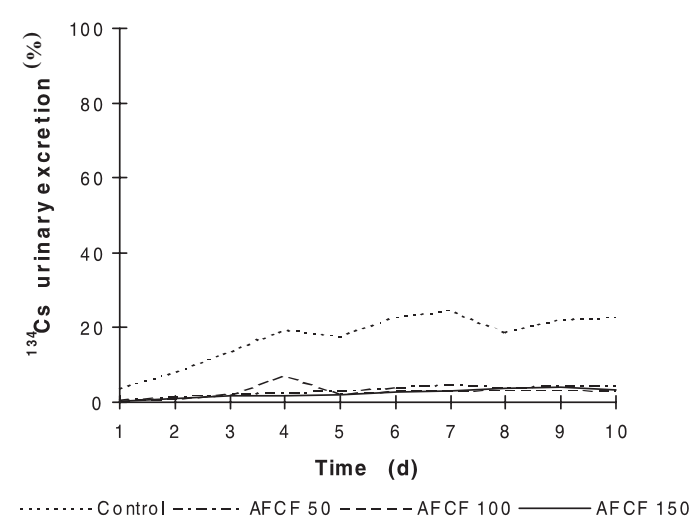

Fig. 2. Effect of different doses of ammonium ferric hexacyanoferrate (AFCF) $\left(50,100\right.$ and $\left.150 \mathrm{mg} \mathrm{d}^{-1}\right) \mathrm{on}^{134} \mathrm{Cs}$ faecal (a) and urinary (b) excretion (\% of intake) during ten days. (experiment 2 ) 
Paasikallio, A. et al. Effect of AFCF on reducing ${ }^{134}$ Cs transfer from grass silage to sheep

Table 5. Mean ${ }^{134} \mathrm{Cs}$ excretion (\% of intake) in faeces and urine and the faecal/urinary ratio (F/U) of sheep administered ${ }^{134} \mathrm{Cs}$ contaminated silage daily with different doses of ammonium ferric hexacyanoferrate (AFCF).

\begin{tabular}{|c|c|c|c|c|c|c|c|}
\hline \multirow{3}{*}{$\begin{array}{c}\text { AFCF } \\
\text { dose } \\
\left(\mathrm{mg} \mathrm{d}^{-1}\right)\end{array}$} & \multirow[b]{3}{*}{$\mathrm{n}$} & \multirow{3}{*}{$\begin{array}{l}\text { Test } \\
\text { period } \\
\text { (d) }\end{array}$} & \multicolumn{4}{|c|}{${ }^{134} \mathrm{Cs}$ excretion $(\%)$} & \multirow{3}{*}{$\begin{array}{r}{ }^{134} \mathrm{Cs} \\
\text { F/U }\end{array}$} \\
\hline & & & \multicolumn{2}{|c|}{ Faeces } & \multicolumn{2}{|c|}{ Urine } & \\
\hline & & & Mean & SD & Mean & SD & \\
\hline \multicolumn{8}{|c|}{ Experiment 1} \\
\hline 0 & 2 & 14 & 41 & 15 & 16 & 6 & 3 \\
\hline $21^{\mathrm{a}}$ & 2 & 14 & 52 & 16 & 11 & 4 & 5 \\
\hline 21 & 2 & 14 & 59 & 18 & 6 & 3 & 10 \\
\hline \multicolumn{8}{|c|}{ Experiment 2} \\
\hline 0 & 3 & 10 & 34 & 16 & 17 & 8 & 2 \\
\hline 50 & 3 & 10 & 69 & 21 & 3 & 1 & 23 \\
\hline 100 & 3 & 10 & 75 & 28 & 3 & 3 & 33 \\
\hline 150 & 3 & 10 & 69 & 26 & 2 & 2 & 42 \\
\hline
\end{tabular}

$\mathrm{n}=$ number of sheep, $\mathrm{SD}=$ standard deviation

a AFCF given in capsule, others in silage

Table 6. Activity concentration (least square mean with $95 \%$ confidence interval) and reduction (\% of control) of ${ }^{134} \mathrm{Cs}$ in sheep tissues after administering ${ }^{134} \mathrm{Cs}$ contaminated silage daily, without ammonium ferric hexacyanoferrate (AFCF) (control) and with different doses of AFCF given in silage for 10 days (experiment 2).

\begin{tabular}{|c|c|c|c|c|c|c|c|c|c|}
\hline \multirow[t]{3}{*}{ Tissue } & \multicolumn{7}{|c|}{${ }^{134} \mathrm{Cs}$ in sheep } & \multicolumn{2}{|c|}{ Significance } \\
\hline & \multirow{2}{*}{$\begin{array}{c}\text { Control } \\
\left(\mathrm{Bq} \mathrm{kg}^{-1}\right)\end{array}$} & \multicolumn{2}{|c|}{ AFCF $50 \mathrm{mg} \mathrm{d}^{-1}$} & \multicolumn{2}{|c|}{ AFCF $100 \mathrm{mg} \mathrm{d}^{-1}$} & \multicolumn{2}{|c|}{ AFCF $150 \mathrm{mg} \mathrm{d}^{-1}$} & \multirow[b]{2}{*}{$\mathrm{P}_{1}$} & \multirow[b]{2}{*}{$\mathrm{P}_{2}$} \\
\hline & & $\left(\mathrm{Bq} \mathrm{kg}^{-1}\right)$ & $(\%)$ & $\left(\mathrm{Bq} \mathrm{kg}^{-1}\right)$ & $(\%)$ & $\left(\mathrm{Bq} \mathrm{kg}^{-1}\right)$ & $(\%)$ & & \\
\hline Muscle & $\begin{array}{c}2205 \\
(1662,2925)\end{array}$ & $\begin{array}{c}557 \\
(420,739)\end{array}$ & 75 & $\begin{array}{c}393 \\
(296,521)\end{array}$ & 82 & $\begin{array}{c}305 \\
(230,405)\end{array}$ & 86 & $<0.005$ & 0.78 \\
\hline Heart & $\begin{array}{c}2407 \\
(1814,3193)\end{array}$ & $\begin{array}{c}620 \\
(467,823)\end{array}$ & 74 & $\begin{array}{c}465 \\
(350,617)\end{array}$ & 81 & $\begin{array}{c}393 \\
(296,521)\end{array}$ & 84 & 0.03 & 0.72 \\
\hline Liver & $\begin{array}{c}2756 \\
(2077,3657)\end{array}$ & $\begin{array}{c}641 \\
(483,851)\end{array}$ & 77 & $\begin{array}{c}545 \\
(411,723)\end{array}$ & 80 & $\begin{array}{c}447 \\
(337,593)\end{array}$ & 84 & 0.08 & 0.92 \\
\hline Kidney & $\begin{array}{c}4524 \\
(3410,6002)\end{array}$ & $\begin{array}{c}1065 \\
(802,1413)\end{array}$ & 76 & $\begin{array}{c}748 \\
(563,992)\end{array}$ & 85 & $\begin{array}{c}698 \\
(526,926)\end{array}$ & 85 & 0.04 & 0.41 \\
\hline Diaphragm & $\begin{array}{c}2652 \\
(1999,3519)\end{array}$ & $\begin{array}{c}682 \\
(514,905)\end{array}$ & 74 & $\begin{array}{c}461 \\
(347,612)\end{array}$ & 83 & $\begin{array}{c}402 \\
(303,534)\end{array}$ & 85 & 0.01 & 0.45 \\
\hline
\end{tabular}

Number of sheep per treatment $=3$, muscle is a mean of neck and femural muscles, $\mathrm{P}_{1}=$ linear trend and $\mathrm{P}_{2}=$ quadratic trend of AFCF levels without control. 


\section{AGRICULTURAL AND FOOD SCIENCE IN FINLAND}

Vol. 9 (2000): 135-147.

\section{Discussion}

\section{Reduction of ${ }^{134} \mathrm{Cs}$}

In this study, the lowest AFCF dose of $21 \mathrm{mg} \mathrm{d}^{-1}$ fed in silage, reduced the final ${ }^{134} \mathrm{Cs}$ activity concentration in ovine muscle by $46 \%$, which was further decreased by $86 \%$ at the highest dose of $150 \mathrm{mg} \mathrm{d}^{-1}$. According to Pearce et al. (1989), a bolus providing AFCF $20-24 \mathrm{mg} \mathrm{d}^{-1}$ reduced the ${ }^{137} \mathrm{Cs}$ level of sheep muscle by $42 \%$ and in animals receiving $200 \mathrm{mg} \mathrm{d}^{-1}$ the reduction was $85 \%$. Intakes of AFCF from salt licks or boli of between 25-300 $\mathrm{mg} \mathrm{d}^{-1}$, have reduced the transfer of ${ }^{137} \mathrm{Cs}$ to sheep tissue by $50-90 \%$ (Hove 1993). In reindeer, an AFCF dose of $500 \mathrm{mg} \mathrm{d}^{-1}$ prevented the absorption of ${ }^{137} \mathrm{Cs}$ almost completely (Åhman 1996). A comparison of the current results with those documented in the literature, indicates that incubation with silage did not reduce the efficacy of AFCF to inhibit radiocaesium transfer to sheep tissues. In this respect, the use of AFCF would be suitable for field conditions. The AFCF doses used in the present study were considerably lower than those generally recommended for small ruminants (1-2 g $\mathrm{d}^{-1}$ ) (Giese 1988, 1989). Silage AFCF contents, as high as $500 \mathrm{mg} \mathrm{kg}^{-1}$, would not exceed recommended AFCF daily doses in sheep fed that silage $3 \mathrm{~kg} \mathrm{~d}^{-1}$.

In experiment $1, \mathrm{AFCF}$ given in silage, was more effective in reducing tissue ${ }^{134} \mathrm{Cs}$ levels than the same dose of AFCF administrated via capsules. Administered in silage, AFCF may have bound ${ }^{134} \mathrm{Cs}$ during ensiling, whilst when $\mathrm{AFCF}$ is given in capsule form, ${ }^{134} \mathrm{Cs}$ probably has a greater chance of being transferred to tissues before AFCF is released into the rumen. This hypothesis was supported by digesta activity concentrations, since ${ }^{134} \mathrm{Cs}$ activity concentrations in the rumen-abomasum content of animals receiving AFCF in silage was higher than in capsule fed animals. Radiocaesium activity concentrations of control sheep was significantly higher in renal than in other tissues, which is in accordance with other studies (Howard and Lindley 1985, Howard et al. 1989).

\section{Transfer coefficients}

In control animals, the transfer coefficient for radiocaesium from feed to muscle averaged $0.15 \mathrm{~d} \mathrm{~kg}^{-1}$. The value was rather low compared, particularly, to those of post-Chernobyl studies (Howard et al. 1987, 1989, Andersson 1989, Beresford et al. 1989, Howard 1989). The low value was probably due to the short feeding periods (10 and 14 days) used in the current study. The transfer coefficients for radiocaesium are valid only when the radiocaesium level of tissue has equilibrated with intake, which in sheep is attained between 20 and 30 days post-contamination (Howard et al. 1989, Pearce et al. 1989).

\section{Excretion of $134 \mathrm{Cs}$}

A plateau for faecal ${ }^{134} \mathrm{Cs}$ excretion seems to be reached after 5-6 days from the beginning of the experiment (large day-to-day variation). This was a rather short period compared to the findings of Vandecasteele et al. (1989) who reported a faecal excretion plateau after 20 days in pregnant ewes. In control sheep, faecal ${ }^{134} \mathrm{Cs}$ excretion was twice that in urine. Mean faecal ${ }^{134} \mathrm{Cs}$ excretion accounted for $38 \%$ of intake, which was somewhat lower than values $(50 \%)$ reported by Beresford et al. (1989) and Vandecasteele et al. (1989). However, the contamination period in their studies was much longer (34 and 76 days, respectively) than in the present experiment. The administration of AFCF mixed in silage increased faecal ${ }^{134} \mathrm{Cs}$ excretion considerably in this study, and was attributed to AFCF inhibition of ${ }^{134} \mathrm{Cs}$ intestinal absorption. 
Paasikallio, A. et al. Effect of AFCF on reducing ${ }^{134}$ Cs transfer from grass silage to sheep

\section{Conclusion}

Adding AFCF to contaminated silage considerably reduced ${ }^{134} \mathrm{Cs}$ transfer to sheep tissues. Incubation in silage did not reduce the efficacy of $\mathrm{AFCF}$ as a Cs-binder. In this respect, use of AFCF in the field would be possible. However, additional studies are needed to develop spraying technics for AFCF application during ensiling in combination with formic acid or enzyme inoculant silage additives under field conditions. Furthermore, long term studies are required to validate ${ }^{134} \mathrm{Cs}$ transfer coefficients, since the feeding period was too short to reach equilibrium between tissue and feed ${ }^{134} \mathrm{Cs}$ in the current study.

Acknowledgements. We thank Ms Päivi Vähämäki, Ms Taina Lilja and Ms Helvi Kananen for their invaluable assistance. We also thank Mr Lauri Jauhiainen for statistical expertise.

\section{References}

Åhman, B. 1996. Effect of bentonite and ammoniumferric(III)-hexacyanoferrate(II) on uptake and elimination of radiocaesium in reindeer. Journal of Environmental Radioactivity 31: 29-50.

Andersson, I. 1989. Transfer of ${ }^{137} \mathrm{Cs}$ from feed to lambs' meat and the influence of feeding bentonite. Swedish Journal of Agricultural Research 19: 85-92.

Arnaud, M.J., Clement, C., Getaz, F., Tannhauser, F., Schoenegge, R., Blum, J. \& Giese, W. 1988. Synthesis, effectiveness and metabolic fate in cows of the caesium complexing compound ammonium ferric hexacyanoferrate labelled with ${ }^{14} \mathrm{C}$. Journal of Dairy Research 55: 1-13.

Beresford, N.A., Lamb, C.S., Mayes, R.W., Howard, B.J. \& Colgrove, P.M. 1989. The effect of treating pastures with bentonite on the transfer of ${ }^{137} \mathrm{Cs}$ from grazed herbage to sheep. Journal of Environmental Radioactivity 9: 251-264.

Commission Directive 1996. Commission Directive 96/66/EC of 14 October 1996. Official Journal of the European Communities No. L 272/32-35.

Giese, W.W. 1988. Ammonium-ferric-cyano-ferrate(II) (AFCF) as an effective antidote against radiocaesium burdens in domestic animals and animal derived foods. British Veterinary Journal 144: 363369.

- 1989. Countermeasures for reducing the transfer of radiocesium to animal derived foods. The Science of the Total Environment 85: 317-327.

Gumperetz, M.L. \& Brownie, C. 1993.Repeated measures in randomized block and split-plot experiments. Canadian Journal of Forest Research 23: 625--639.

Hansen, H.S., Hove, K. \& Barvik, K. 1996. The effect of sustained release boli with ammoniumiron(III)-hexacyanoferrate(II) on radiocesium accumulation in sheep grazing contaminated pasture. Health Physics 71: 705-712.
Hazzard, D.G. 1969. Percent cesium-134 and strontium -85 in milk, urine, and feces of goats on normal and verxite-containing diets. Journal of Dairy Science 52: 990-994.

Hove, K. 1993. Chemical methods for reduction of the transfer of radionuclides to farm animals in seminatural environments. The Science of the Total Environment 137: 235-248.

-, Hansen, H.S. \& Strand, P. 1990. Experience with the use of caesium binders to reduce radiocaesium contamination of grazing animals. In: Environmental Contamination Following a Major Nuclear Accident 2. Proceedings of a Symposium of FAO, IAEA, UNEP, WHO. Vienna. p. 181-189.

Howard, B.J. 1989. A comparison of radiocaesium transfer coefficients for sheep milk and muscle derived from both field and laboratory studies. The Science of the Total Environment 85: 189-198.

-, Beresford, N.A., Burrow, L., Shaw, P.V. \& Curtis, E.J.C. 1987. A comparison of caesium 137 and 134 activity in sheep remaining on upland areas contaminated by Chernobyl fallout with those removed to less active lowland pasture. Journal of the Society for Radiological Protection 7: 71-73.

- \& Lindley, D.K. 1985. Aspects of the uptake of radionuclides by sheep grazing on an estuarine saltmarsh. 2. Radionuclides in sheep tissues. Journal of Environmental Radioactivity 2: 199-213.

-, Mayes, R.W., Beresford, N.A. \& Lamb, C.S. 1989. Transfer of radiocesium from different environmental sources to ewes and suckling lambs. Health Physics 57: 579-586.

IAEA 1997. The use of Prussian Blue to reduce radiocaesium contamination of milk and meat produced on territories affected by the Chernobyl accident. IAEA-TECDOC-926. Report of United Nations Project E 11. International Atomic Energy Agency. Vienna. $80 \mathrm{p}$. 
Vol. 9 (2000): 135-147.

Johnson, J.E., Ward, G.M., Firestone, E. \& Knox, K.L. 1968. Metabolism of radioactive cesium $\left({ }^{134} \mathrm{Cs}\right.$ and ${ }^{137} \mathrm{Cs}$ ) and potassium by dairy cattle as influenced by high and low forage diets. Journal of Nutrition 94: 282-288.

Jones, D.R., Paul, L. \& Mitchell, N.G. 1999. Effects of ameliorative measures on the radiocaesium transfer to upland vegetation in the UK. Journal of Environmental Radioactivity 44: 55-69.

Lipsztein, J.L., Bertelli, L., Oliveira, C.A.N. \& Dantas, B.M. 1991. Studies of Cs retention in the human body related to body parameters and Prussian Blue administration. Health Physics 60: 57-61.

Madhus, K., Strömme, A., Bohne, F. \& Nigrovic, V. 1966. Diminution of radiocaesium body-burden in dogs and human beings by Prussian Blue. International Journal of Radiation Biology 10: 519-520.

Melo, D.R., Lipsztein, J.L., de Oliveira, A.N. \& Bertelli, L. 1994. ${ }^{137} \mathrm{Cs}$ internal contamination involving a Brazilian accident, and the efficacy of Prussian Blue treatment. Health Physics 66: 245-252.

Mitchell, N.G., Coughtrey, P.J., Beetham, C.J., Hughes, J.G., Clench, S.F. \& Walters, B. 1989. Transfer of caesium from silage to cows milk: observations and models. The Science of the Total Environment 85: 307-316.

Nielsen, P., Dresow, B., Fischer, R. \& Heinrich, H.C. 1990. Bioavailability of iron and cyanide from oral potassium ferric hexacyanoferrate(II) in humans. Archives of Toxicology 64: 420-422.

Nigrovic, V. 1963. Enhancement of the excretion of radiocaesium in rats by ferric cyanoferrate (II). International Journal of Radiation Biology 7: 307-309.

Oughton, D.H., Day, J.P., Howard, B.J., Beresford, N.A., Lamb, C.S., Mayes, R.W., Preston, T. \& East, B.W. 1991. Caesium dosing reduces uptake of radiocesium by sheep. Journal of Environmental Radioactivity 14: 105-121.

Pearce, J. 1994. Studies of any toxicological effects of Prussian Blue compounds in mammals- a review. Food and Chemical Toxicology 32: 577-582.

-, Unsworth, E.F., McMurray, C.H., Moss, B.W., Logan, E., Rice, D. \& Hove, K. 1989. The effects of Prussian Blue provided by indwelling rumen boli on the tissue retention of dietary radiocaesium by sheep. The Science of the Total Environment 85: 349-355.
Phillippo, M., Gvozdanovic, S., Gvozdanovic, D., Chesters, J.K., Paterson, E. \& Mills, C.F. 1988. Reduction of radiocaesium absorption by sheep consuming feed contaminated with fallout from Chernobyl. Veterinary Record 122: 560-563.

SAS, 1992. SAS/STAT Software: Changes and Enhancements, Release 6.07, SAS Technical Report P-229, Statistical Analysis Systems Institute Inc., Cary, NY. 620 p.

Unsworth, E.F., Pearce, J., McMurray, C.M., Moss, B.V., Gordon, F.J. \& Rice, D. 1989. Investigations of the use of clay minerals and Prussian Blue in reducing the transfer of dietary radiocaesium to milk. The Science of the Total Environment 85: 339-347.

Vandecasteele, C.M., Van Hees, M., Culot, J.P. \& Vankerkom, J. 1989. Radiocaesium metabolism in pregnant ewes and their progeny. The Science of the Total Environment 85: 213-223.

Vandenhove, H., Van Hees, M., De Brouwer, S. \& Vandecasteele, C. 1997. Effects of ammonium-ferric (III)-hexacyano-ferrate(II) and faeces addition on yield and soil-plant transfer of radiocaesium to ryegrass. Journal of Environmental Radioactivity 37: 235-246.

-, Van Hees, M. \& Vandecasteele, C.M. 1998. Effectiveness of immediate and delayed AFCF application in reducing radiocaesium transfer to ryegrass. Journal of Environmental Radioactivity 41: 47-63.

-, Van Hees, M. \& Vandecasteele, C. 2000. Potential side effects of ammonium-ferric-hexacyano-ferrate application: enhanced radiostrontium transfer and free cyanide release. Journal of Environmental Radioactivity 47: 149-155.

Voigt, G. 1993. Chemical methods to reduce the radioactive contamination of animals and their products in agricultural ecosystems. The Science of the Total Environment 137: 205-225.

Vreman, K., van den Hoek, J., van der Struijs, T.D.B. 1992. Administration of ammonium ferric hexacyanoferrate strongly reduces radiocaesium contamination of cows' milk. Netherlands Milk and Dairy Journal 46: 81-88.

Wolfinger, R. 1996. Heterogeneous variance-covariance structures for repeated measures. Journal of Agricultural, Biological, and Environmental Statistics 1: 205-230. 
Paasikallio, A. et al. Effect of AFCF on reducing ${ }^{134}$ Cs transfer from grass silage to sheep

\title{
SELOSTUS
}

\section{Lihan ${ }^{134}$ Cs-aktiivisuuspitoisuuden vähentäminen ferriheksasyanoferraatin avulla}

\author{
Arja Paasikallio, Riitta Sormunen-Cristian, Seija Jaakkola ja Matti Kaikkonen \\ Maatalouden tutkimuskeskus ja Helsingin yliopisto
}

Radiocesiumin kulkeutumista märehtijöihin on voitu vähentää syöttämällä eläimille erilaisia cesiumia sitovia mineraaleja kuten esimerkiksi bentoniittia, zeoliittia, vermikuliittia ja kaoliinia sekä kuitupitoista rehua. Ferriheksasyanoferraatit (preussinsininen, PB-yhdisteet) ovat edellisiä huomattavasti tehokkaampia cesiumsitojia. Ammoniumferriheksasyanoferraatti (AFCF) on PB-yhdisteistä tehokkaimpia ja eniten tutkittu. AFCF sitoo itseensä radiocesiumia vaihtaen sen ammoniumioniin. Koska PB ei imeydy ruoansulatuskanavasta kudoksiin, poistuu radiocesium eläimestä PB-yhdisteeseen sitoutuneena sonnan mukana. Paras tulos saavutetaan kun cesiumsitojaa syötetään samanaikaisesti aktiivisen rehun kanssa. Joissakin tapauksissa sitojan on myös todettu poistavan elimistössä jo olevaa radiocesiumia. Sisätiloissa PB:tä tavallisesti syötetään eläimille kerran pari päivässä sekoittamalla sitä pieneen määrään rehua. Laitumella sitojaa voidaan helpoimmin antaa lisäämällä sitä nuolukiveen tai bolukseen. Lukuisten tutkimusten perusteella PB-yhdisteitä voidaan pitää vaarattomina eläimille ja ihmisille, sillä yhdisteiden ei ole todettu havaittavissa määrin hajoavan ja imeytyvän kudoksiin ja maitoon.

Tutkimuksen tarkoituksena oli selvittää pienten AFCF-määrien, joita muhitettiin aktiivisessa säilörehussa sen kypsymisen ajan, vaikutusta radiocesiumin kulkeutumiseen lampaan kudoksiin. Muhittamisen vaikutusta cesiumsitojan tehokkuuteen ei ole aikaisemmin selvitetty. Tutkimuksen taustalla oli ajatus, että laskeumatilanteessa AFCF voitaisiin ruiskuttaa, kuten säilöntäainekin, saastuneeseen ruohoon jo pellolla sadonkorjuun yhteydessä.

AFCF:n vaikutusta tutkittiin puolivuotiailla pässikaritsoilla, joita pidettiin aineenvaihduntahäkeissä. Raiheinää kasvatettiin astiakokeissa turvemaassa, johon oli lisätty ${ }^{134} \mathrm{Cs}$ :a. Näin saatua aktiivista raiheinää lisättiin silputtuun pellolla kasvatettuun raiheinään, ja seokseen ruiskutettiin säilöntäainetta sekä veteen sekoitettua AFCF:ia. Säilörehun valmistuttua se jaettiin päiväannoksiin. Lampaille syötettiin AFCF:ia päivittäin neljäntoista päivän ajan $21 \mathrm{mg}$ kapselissa ja 21 mg rehussa (koe 1) ja päivittäin kymmenen päi- vän ajan 50, 100 ja $150 \mathrm{mg}$ rehussa (koe 2). Kontrollilampaat eivät saaneet AFCF:ia.

Kudosten ${ }^{134} \mathrm{Cs}$ - aktiivisuuspitoisuus oli yleensä korkein munuaisissa ja matalin lihaksessa. Jo pienetkin AFCF-määrät vähensivät selvästi lampaan lihan ${ }^{134} \mathrm{Cs}$-aktiivisuuspitoisuutta. Rehun mukana annettu päivittäinen $21 \mathrm{mg}$ AFCF-annos vähensi radiocesiumin kulkeutumista lampaan lihakseen $45 \%$ kontrollieläimeen verrattuna. Sama AFCF-määrä annettuna kapselissa vähensi kulkeutumista $3 \%$. Eläinten saadessa päivittäin aktiivisen rehun mukana 50, 100 ja $150 \mathrm{mg}$ AFCF:ia väheni radiocesiumin kulkeutuminen lihakseen 75,82 ja $86 \%$. Tässä tutkimuksessa käytetyt AFCF-määrät olivat pienille märehtijöille suositeltuja annoksia (1-2 g päivässä) huomattavasti pienempiä.

Lihas/rehu-siirtokertoimet laskettiin jakamalla lihaksen ${ }^{134} \mathrm{Cs}$-aktiivisuuspitoisuus $\left(\mathrm{Bq} \mathrm{kg}^{-1}\right)$ päivittäisen rehuannoksen sisältämällä ${ }^{134} \mathrm{Cs}$-määrällä $(\mathrm{Bq}$ $\mathrm{d}^{-1}$ ). Kokeessa 1 siirtokertoimet olivat 0,14 (kontrolli), 0,14 (kapseli) ja 0,07 d kg-1 (rehu). Kokeessa 2 kontrollieläinten siirtokerroin oli 0,16 ja muiden keskimäärin $0,03 \mathrm{~d} \mathrm{~kg}^{-1}$. Kontrollieläinten siirtokertoimet olivat pienempiä kuin useissa Tshernobylin jälkeen suoritetuissa tutkimuksissa, minkä katsottiin johtuvan tämän tutkimuksen kokeiden lyhytaikaisuudesta. Eräiden selvitysten mukaan tasapaino kudosten radiocesiumpitoisuuden ja radiocesiumin jatkuvan saannin välillä saavutetaan lampailla vasta noin 20-30 päivän kuluttua.

Radiocesiumin erittyminen sonnan mukana oli kontrollilampailla selvästi vähäisempää ja virtsan mukana runsaampaa kuin AFCF:ia saaneilla lampailla. Kun rehussa annetun AFCF:n päiväannosta nostettiin 0:sta $21 \mathrm{mg}$ :aan, radiocesiumin keskimääräinen erittyminen sonnan mukana oli vastaavasti 41 ja $59 \%$ ja virtsan mukana 16 ja $6 \%$ radiocesiumin saannista (koe 1). Kun AFCF-annosta nostettiin 0:sta 150 mg:aan, vastaavat radiocesiumin erittymismäärät olivat sonnassa 34 ja $69 \%$ ja virtsassa 17 ja $2 \%$ (koe 2).

Tutkimuksessa saatiin alustavaa tietoa aktiivisessa säilörehussa muhineen AFCF:n vaikutuksesta lampaan lihan radiocesiumtasoon. AFCF:n muhitta- 


\section{AGRICULTURAL AND FOOD SCIENCE IN FINLAND}

Vol. 9 (2000): 135-147.

minen useita viikkoja säilörehussa ei vähentänyt sen tehoa cesiumsitojana; pienetkin AFCF-määrät vähensivät huomattavasti radiocesiumin kulkeutumista eläimen kudoksiin. Ainakin tältä osin AFCF:n käyttö pellolla olisi mahdollista. AFCF:n ruiskutusteknii- kan kehittämiseksi tarvitaan lisätutkimuksia. Lisäksi lihas/rehu- siirtokertoimien luotettavuuden tarkistaminen vaatisi pitempiaikaisia ruokintakokeita kuin mitä tässä tutkimuksessa oli mahdollista tehdä. 